\title{
JUURNAL_RU
}

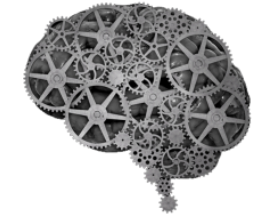

COMPANY GROUP "INTELLEKT"

Сорока Г.Г., Литвинова Л.Н. Городская больнииа № 1 им Н.А. Семашко Ростов-на-Дону, Россия

doi: 10.18411/lj2016-3-34

\section{Исследование механизмов регуляции сосудистого тонуса у подрост-ков с привычными носовыми кровотечениями}

Носовое кровотечение (НК) может быть симптомом различных заболеваний $[1,2,3]$. В ряде случаев остановить НК консервативными методами бывает очень сложно и тогда требуются различные хирургические вмешательства [4, 5]. Установить причину НК не всегда удается, поэтому немалое число кровотечений попадает в группу заболеваний «неясной этиологии».

Около 4\% населения страдает носовыми кровотечениями, повторяющимися несколько раз в год на протяжении длительного времени. Это патологическое состояние описывается понятием «привычные носовые кровотечения». Причинами таких кровотечений, как правило, являются локальные заболевания полости носа: атрофический ринит, перфорация перегородки носа, сосудистые опухоли, варикозное расширение сосудов слизистой оболочки носа $(\mathrm{COH})$. Возможно возникновение привычных НК и при общих заболеваниях, в частности, при геморрагических диатезах. Вместе с тем, среди больных с привычными НК имеется группа лиц, у которых этиология заболевания так и остается невыясненной, поскольку у них не выявляется ни локальных, ни общих причин НК.

Целью нашего исследования было изучение особенностей 
нейрогуморальной регуляции сосудистого тонуса $\mathrm{y}$ подростков с рецидивирующими НК неясной этиологии.

С этой целью мы исследовали содержание биологически активных веществ (БАВ) в крови больных с привычными НК: норадреналина (НА), дофамина (ДА) гистамина (Ги) и серотонина (С) флюорометрическими методами. Забор крови производили из локтевой вены. Для наиболее адекватной оценки механизмов сосудистой регуляции определение содержания биогенных аминов проводили до и после дозированной физической нагрузки $(\Phi Н)-20$ приседаний за 50 секунд. Контрольную группу составили 15 практически здоровых подростков.

Мы наблюдали 18 больных в возрасте от 12 до 17 лет (10 девочек и 8 мальчиков), с детства страдающих рецидивирующими НК. Кровотечения повторялись с частотой 4 и более раз в год на протяжении последних 2-3 лет, возникали как в состояния покоя, так и при различных нагрузках (перегревание, высмаркивание носа, наклоны туловища вперед). Периоды учащения кровотечений чередовались с ремиссиями, причин которых больные указать не могли. Других проявлений кровоточивости не отмечено. Ранее все больные были обследованы в гематологических стационарах, нарушений коагуляционного и тромбоцитарного гемостаза не обнаружено.

Помимо повторных НК, типичными жалобами больных этой группы были головные боли, головокружения, склонность к обморокам и ортостатическим коллапсам, вегетативные пароксизмы, периодически возникающее ощущение сердцебиения. В ходе динамического наблюдения у 8 больных этой группы были зарегистрированы непостоянные и неустойчивые подъемы артериального давления, однако, коррелятивной связи между периодами подъемов АД и учащением НК не выявлено.

При исследовании содержания БАВ отмечено достоверное снижение

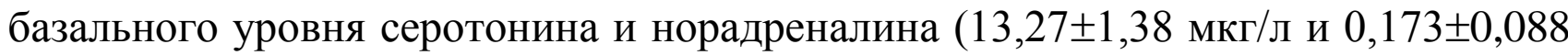

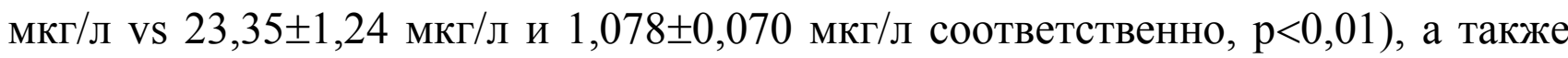


повышение базального уровня гистамина $(42,65 \pm 4,43$ мкг/л p vs 29,75 $\pm 1,97$ мкг/л , $\mathrm{p}<0,02)$ по сравнению с контрольной группой . Содержание ДА оказалось сниженным на $56,9 \%$ по сравнению с контролем $(1,88 \pm 0,54$ и $2,95 \pm 0,47$ мкг/л соответственно).

В ответ на ФН уровень С и ДА у исследуемых больных и в контрольной группе и группах сравнения не изменился. Уровень НА у больных с привычными НК достоверно вырос. Содержание гистамина в крови больных НК после физической нагрузки достоверно снизилось, достигнув нормального уровня, в то время как в контрольной группе оно практически не изменилось.

Выраженное снижение базального уровня норадреналина у больных с привычными НК указывает на истощение адренергических механизмов, поддерживающих вазоконстрикторный эффект сосудов слизистой оболочки полости носа, в результате чего, по всей вероятности, страдает сосудистый компонент гемостаза на этапе первичного спазма сосудов в ответ на повреждение сосудистой стенки.

Снижение базального уровня серотонина может быть существенным фактором нарушения сосудистого гемостаза в фазе пролонгированной вазоконстрикции.

Анализируя полученные результаты, трудно сказать, что является первичным: снижение базального уровня норадреналина, ведущее к развитию тканевой гипоксии и, как следствие, накоплению гистамина, или повышение уровня гистамина, приводящее к подавлению высвобождения норадреналина из нервных окончаний. Однако какими бы ни были причинно-следственные взаимоотношения, очевидно, что увеличение содержания гистамина также вызывает дилатацию емкостных сосудов и капиллярного русла слизистой оболочки полости носа.

Анализ ответной реакции нейрогуморальных структур на физическую нагрузку позволяет оценить адаптационные возможности организма. Адекватной реакцией на физическую нагрузку у здоровых лиц является 
повышение симпатического тонуса вследствие увеличения секреции адренергических медиаторов. Единичные публикации указывают на повышение содержания гистамина в крови в ответ на ФН. В таком случае снижение уровня гистамина после ФН можно рассматривать как срыв адаптивных возможностей механизмов регуляции микроциркуляции.

Таким образом, изменения базального уровня адренергических медиаторов (НА, ДА и С) у подростков с привычными НК и у больных гипертонической болезнью (ГБ), обследованных в период возникновения у них носовых кровотечений $[6,7,8,9]$, оказались весьма похожими. Формирование адаптационных нейрогуморальных реакций в ответ на действие неспецифического стимула у этих больных также имеет сходный характер с таковыми при ГБ в начальной стадии. Не исключено, что НК являются одним из проявлений предрасположенности к развитию гипертонической болезни у данной группы больных 


\section{Литература:}

1. 1. Гаджимирзаев Г.А., Тулкин В.Н., Гаджимирзаев Р.Г. Носовые кровотечения. Аналитический обзор и собственный опыт. Рос. оторинолар. 2014. Т. 72. № 5. С. 96-110.

2. 2. Анготоева И.Б., Курлова А.В., Горносталев Н.Я. Методы остановки носовых кровотечений. Рос. ринология. 2012. Т. 20. № 3. С. 24-30.

3. 3. Бойко Н.В. Носовые кровотечения как осложнение антитромботической терапии. Рос. ринология 2011. Т. 19. № 4. С. 29-32.

4. 4. Волков А.Г., Бойко Н.В., Быкова В.В., Жданов В.Г. Совершенствование способов остановки носового кровотечения. Вестник оторинолар. 2010. № 4. С. 9-12.

5. 5. Бойко Н.В. Хирургическое лечение рецидивирующих носовых кровотечений. Рос. ринология 1999. № 2. С. 29.

6. 6. Бойко Н.В., Шатохин Ю.В., Быкова В.В. Патогенетическое лечение рецидивирующих носовых кровотечений на фоне гипертонической болезни. Рос. ринология 2007. № 2. С. 58.

7. 7. Бойко Н.В., Шатохин Ю.В. Алгоритм оказания неотложной помощи больным с носовым кровотечением. Рос. ринология. 2008. Т. 16. № 1. C. 41-44.

8. 8. Бойко Н.В., Панченко С.Н. Локализованное внутрисосудистое свертывание у больных с носовыми кровотечениями. Новости оторинолар. и логопатол. 2001. № 3. С. 5

9. 9. Бойко Н.В., Шатохин Ю.В. Патогенез носовых кровотечений у больных с артериальной гипертензией. Вестник оторинолар. 2015. Т. 80. № 5. C. 41-45 